Revista Brasileira de Farmacognosia Brazilian Journal of Pharmacognosy 22(4): 760-767, Jul./Aug. 2012

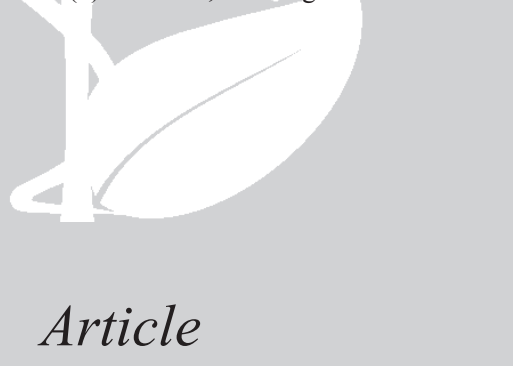

Received 6 Jan 2012

Accepted 3 Feb 2012

Available online 5 Jun 2012

Keywords:

agarose

alginate

carrageenan

The Magellan Region

subantartic marine benthic algae

ISSN 0102-695X

http://dx.doi.org/10.1590/S0102-

$695 \times 2012005000074$

\section{Current knowledge on biotechnological interesting seaweeds from the Magellan Region, Chile}

\author{
Andrés Mansilla, ${ }^{* 1}$ Marcela Ávila, ${ }^{2}$ Nair S. Yokoya ${ }^{3}$ \\ ${ }^{1}$ Laboratorio de Macroalgas Antárticas y Subantárticas, Universidad de \\ Magallanes, Chile, and Institute of Ecology and Biodiversity, Chile, \\ ${ }^{2}$ Institute of Science and Technology, Universidad Arturo Prat, Chile, \\ ${ }^{3}$ Núcleo de Pesquisas em Ficologia, Instituto de Botânica, Secretaria de Estado \\ do Meio Ambiente, São Paulo, Brazil.
}

\begin{abstract}
This paper is a compilation of data from investigations made with marine benthic algae from the Magellan Region that have biotechnological utilization in human consumption or medicine or as a source of phycolloids or food supplements or animal feed. The most important Rhodophyta species are: Ahnfeltia plicata (Hudson) E.M. Fries for agarose production, Gigartina skottsbergii Setchell \& N.L.Gardner for carrageenan production, and Callophyllis variegata (Bory de Saint-Vincent) Kützing for human consumption. The most important Heterokontophyta species are: Macrocystis pyrifera (L.) C. Agardh, and Durvillaea antarctica (Chamisso) Hariot for human consumption, alginate production, and as biofertilizer for agricultural crops. M. pyrifera is also used as a food supplement for salmon, chickens, quails, sheep and bovines and for biofuel production.
\end{abstract}

\section{Introduction}

The Magellan Region, also known as Southern Chile, is located in the southwestern part of the South American continent $\left(48^{\circ} 36^{\prime}\right.$ to $56^{\circ} \mathrm{S} ; 6^{\circ} 25^{\prime}$ to $\left.75^{\circ} 40^{\prime} \mathrm{W}\right)$, and has an area of $132,033.5 \mathrm{~km}^{2}$ (Pérez, 2000). It is characterized by diverse marine habitats, which are determined by geomorphological factors, depth, orientation and exposure to waves, marine currents and contributions of continental and glacial waters. It is considered to be a representative area of subantarctic environments of great extension (Rozzi et al., 2008). It represents the southernmost territory of the South American continent, which, up to the moment, has been reasonably protected from the impact of human activities. A total of 488 species of benthic marine algae have been reported for the coast of continental Chile, of which 87 belong to Chlorophyta, 103 to Heterokontophyta, and 298 to Rhodophyta.

For the Magellan region, recent systematic studies (Mansilla et al. in preparation) report a total of 395 species collected on the coasts of the Strait of Magellan, the Beagle Channel and Cape Horn, of which 75 species belong to Chlorohyta, 86 to Heterokontophyta, and 230 to Rhodophyta, which are distributed in 58 families and 143 species. According to Ramírez (1995), 50.6\% of endemic species have been recorded in the Magellan Region.
The marine macroalgae (red, brown and green algae) are important as primary producers and as raw material for the production of phycocolloids such as agar, carrageenan, agarose and alginate, used in the food, pharmaceutical and cosmetic industries. Nowadays, several species of macroalgae have been cultivated to produce biomass to supply the increasing global demand. As an agricultural crop, seaweed cultivation might regulate the excess of $\mathrm{CO}_{2}$, nitrogen and phosphorus in the ecosystem. Algal biotechnology has achieved great advances in the last three decades, mainly for microalgae, which are cultivated for the production of carotenoids and glycerol (Stanley, 1987). The capacities of carotenoids to act as antioxidants and inmunomodulatory agents have led to active investigations of their potential application in the prevention of carcinogenic disease.

Other uses of macroalgae are orientated toward biofuel production, mainly Macrocystis pyrifera (L.) C. Agardh (Heterokontophyta) for bioalcohol production. Chile mandated the replacement of approximately $5 \%$ of the consumption of petroleum by the year 2010 (Comisión Nacional de Energía, 2007). For biofuel production, the use of alternative raw materials like macroalgae for bioethanol production presents several advantages: a) it produces less pollution; b) it emits less pollutant gases; c) it does not contribute to the emission of carbon dioxide or sulphur; d) it helps to diminish global warming; e) it 
does not use drinkable water; f) it produces neither waste nor garbage; g) $\mathrm{CO}$ and $\mathrm{CO}_{2}$ are captured directly from industrial sources, among others; and h) it does not occupy cultivable terrestrial areas that can be destined to produce food.

Other potential uses of macroalgae, mainly those of the Subantarctic and Antarctic regions, include the accumulation of substances that absorb UV radiation (photoprotectors) and the activation of antioxidant systems. The mycosporine-like amino acids (MAA) are among the best known photoprotectors, with both photoprotector and antioxidant capacities. On the other hand, several references emphasize the other physiological functions of the MAA, including antioxidant activity, osmotic regulation and in breeding.

In the Magellan Region, the macroalgae $M$. pyrifera and Porphyra columbina Montagne (Bangiales, Rhodophyta) have been directly consumed as food (in soups, stews and salads) for many years. Among the red algae existing in the Magellan Region and the Chilean Antarctica, only $P$. columbina, known as "luche", is usually consumed by the population. "Luche" grows in the middle and high regions of the intertidal zone of rocky shores.

Nowadays, increasing tourism in the region has opened the possibility of diversifying the use of subantarctic macroalgae for human consumption, through the transfer of scientific knowledge to the local fishermen. The development of a pilot experiment for gastronomic activity that favors the regional identity of Tourism of Special Interests can generate new possibilities for the use of subantarctic macroalgae and also new options for the fishermen and their families who currently focus their efforts almost exclusively on the extraction of sea urchins and king crabs, which are progressively more overexploited every day. At the same time, the use of macroalgae in the human diet might have positive impacts on the health of the population, who currently incorporate relatively few vegetables into their diets.

\section{Materials and Methods}

This study is a compilation of data from investigations made with marine benthic algae from the Magellan Region that are utilized for human consumption or medicine or as a source of phycolloids, food supplements or animal feed. In this work we focus on Rhodophyta species [Ahnfeltia plicata (Hudson) E.M. Fries, Callophyllis variegata (Bory de SaintVincent) Kützing, and Gigartina skottsbergii Setchell \& N.L.Gardner], and Heterokontophyta species [Durvillaea antarctica (Chamisso) Hariot, and Macrocystis pyrifera (L.) C. Agardh].

\section{Results and Discussion}

Important red algae in the Magellan Region and Chilean Antarctica

In the Magellan Region, some species of red algae of economic importance are collected by fishermen and companies to produce phycocolloids with commercial value.

\section{Gigartina skottsbergii Setchell \& N.L.Gardner (Gigartinales, Rhodophyta)}

G. skottsbergii is a carrageenan-producing species, endemic to the Southern region of South America (Ramirez \& Santelices, 1991; Buschmann et al., 2008). It is known by the common name of "luga roja" or "cuero de chancho". On the coast of Chile, it is distributed from Corral (39 88' S) (Westermeier \& Ramírez, 1978, Ramirez \& Santelices, 1991) to the Antarctic Peninsula (63 23'S) (Bischoff-Bäsmann \& Wiencke, 1996). On the coast of Argentina, it is present in Patagonia from Puerto Madryn ( $\left.42^{\circ} 08^{\prime} \mathrm{S}\right)$, Chubut, to the southern coast of Argentina and subantarctic islands (Piriz, 1996). It occurs in subtidal areas, forming abundant populations in protected environments. The Magellan Region is the main producer of $G$. skottsbergii biomass of the country, with the production of near twenty thousand tons of dry alga. In the region, this alga is harvested exclusively from natural populations. Other carrageenan-producing macroalgae in the region that are not yet commercialized are: Iridaea cordata (Turner) Bory de Saint-Vincent, Mazzaella laminariodes (Bory de Saint-Vincent) Fredericq, and Sarcothalia crispata (Bory de Saint-Vincent) Leister.

G. skottsbergii presents a thick, fleshy, erect red-purple laminar thallus that grows attached to rocks (Figure 1 A-B), pebbles, stones and bivalve shells like Aulacomya ater. It is arranged horizontally on the substrate and remains attached by holdfasts and by several haptera that develop in different parts of the frond. This form of growth limits the availability of substrate, reducing the development of other species. The life cycle is isomorphic, of the Polysiphonia type. The carposporophytic fronds present protruding cystocarps in papillae distributed over the entire surface of the frond. Male fronds have no papillae. The tetrasporangial sori are located on the edge of the cortex and medulla. The frond is of varying size, wider than long, orbicular in form, and can reach up to $1.5 \mathrm{~m}$ in width. They grow at depths ranging from 4 to $30 \mathrm{~m}$ or so, depending on the geographical place and location.

In the past two decades, significant knowledge of the ecology and productivity of natural populations of G. skottsbergii has been obtained and basic aspects of the biology and management of this species have also been 

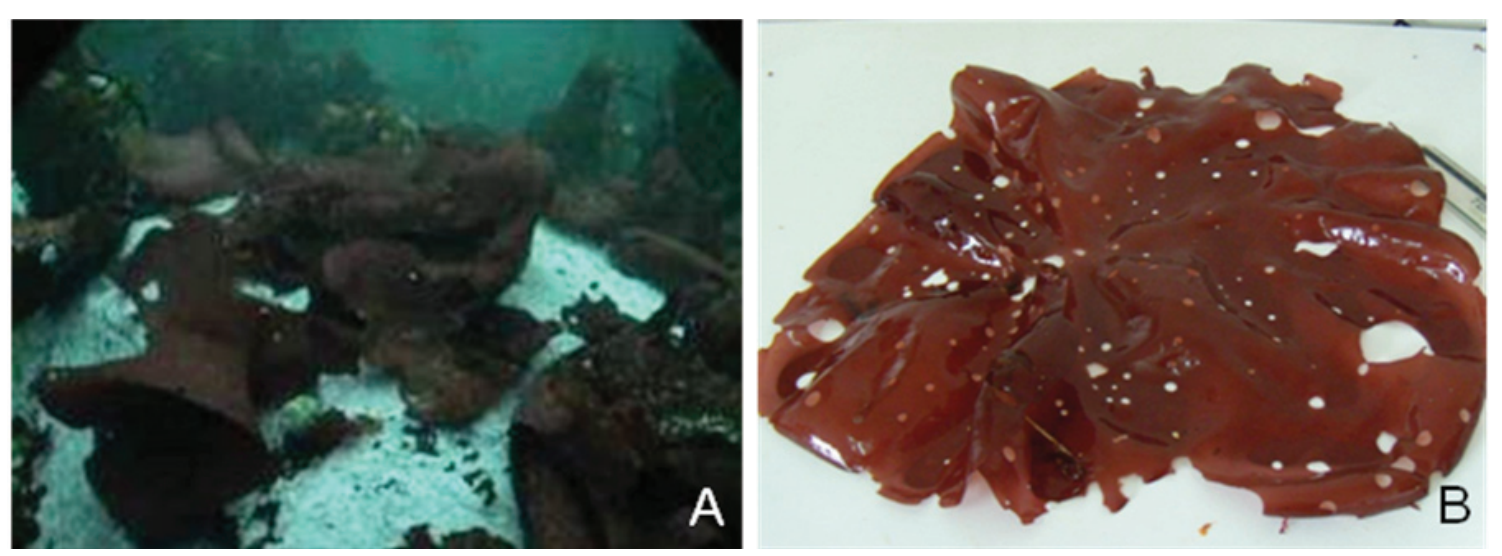

Figure 1. Gigartina skottsbergii (Gigartinales, Rhodophyta): habitat (A) and aspect of thallus (B) collected in Magellan Region, Chile.

studied. This basic knowledge includes aspects such as: the ultrastructure of the spores, phenological studies and population dynamics (Avila et al., 1999a), recruitment in natural populations (Westermeier et al., 1999), vegetative propagation in tanks and in the sea (Hernández-González et al., 2007; Romo et al., 2006; Correa et al., 1999; Westermeier et al., 2012), management (Avila et al.,1999b; Westermeier et al., 2012), and methods of cultivation and repopulation (Avila et al., 1999a; Buschmann et al., 2001; Avila et al., 2003; Buschmann et al., 2004; Romo et al., 2006; Mansilla et al., 2008; Westermeier et al., 2012). Reproductive biological records indicate that this species exhibits seasonality in its sexual reproduction (Zamorano \& Westermeier, 1996) and alternation in the dominance of reproductive stages, similar to that described for other species of Gigartinales (Kim, 1976).

Recently, pilot programs for repopulation of $G$. skottsbergii have been implemented through research projects with the financial support of the Chilean National Commission for Scientific and Technological Research in the region of Los Lagos and the Magellan Region. An educational program for fishermen and their families (Edukaluga Program) has been initiated as part of the project AQI1011 focusing on expanding and strengthening the knowledge that fishermen have about management, repopulation and algal resource sustainability.

\section{Ahnfeltia plicata (Hudson) E.M. Fries (Ahnfeltiales, Rhodophyta)}

A. plicata is considered to be one of the most important agarophytes in the world (Maggs \& Pueschel, 1989), producing agar of high quality and low sulphate content. It is harvested mainly on the Russian coast of the White Sea (Maggs \& Pueschel, 1989). This species is widely distributed, occurring in the North Atlantic Ocean, in the northern North Pacific and southern South Atlantic and South Pacific Oceans (Maggs \& Pueschel, 1989).
In Chile, the occurrence of A. plicata was reported in Tierra del Fuego (Wiencke \& Clayton, 2002), the Magellan Region and the Diego Ramírez Islands (Mansilla \& Navarro, 2003). In the Magellan Region, A. plicata grows on rocky substrates from the intertidal zone to $20 \mathrm{~m}$ in depth, in sheltered or wave-exposed sites. This species is tolerant to a wide range of salinity variation, from 18 to $40 \mathrm{psu}$. Along the exposed coast of Riesco Island (Seno Skyring, Magellan Region), $A$. plicata forms extensive beds, producing a biomass of 3 $\mathrm{kg} \cdot \mathrm{m}^{-2}$ (fresh weight), with a yield of $20 \%$ in dry weight. The salinity of this area is 22 psu (Ortiz et al., 2011).

Samples of Ahnfeltia plicata collected during the spring, summer and autumn from Riesco Island (Magellan Region) showed the presence of agarans (Ortiz et al., 2011). Chemical analysis of agarans obtained in different seasons showed that the content of galactose and 3,6-anhydro-galactose is in a 1:1 ratio and elemental analysis showed that the sulfur content of agarans is less than $0.1 \%$, indicating that the neutral agaran presents the structure of agarose (Ortiz et al., 2011). A. plicata is source of agar with high quality, low sulphate content and high gel strength, even in very low concentrations. This agar is used as a gelling and thickening agent by food industries and as a stabilizing agent by cosmetic and pharmaceutical industries.

The morphology of $A$. plicata gametophytes is represented by erect axes, 3 to $21 \mathrm{~cm}$ long, which arise in tufts from crustose holdfasts $(1 \mathrm{~cm}$ diameter). Branching is generally irregular and variable, with some axes forming dichotomies or irregular branches (Figure 2 A-B). Male gametophytes form spermatangial sori on mature axes and are absent in the apical and basal regions of the axes. Similarly, female sori are formed on mature axes, usually along one side of the axis. The life history of A. plicata from Canada is heteromorphic, involving the erect thallus of gametophytes and crustose tetrasporophytes, which grow very closely appressed to hard substrata (Maggs \& 
Pueschel, 1989). However, the life history of A. plicata from the South Atlantic and South Pacific Oceans remains to be investigated.

\section{Callophyllis variegata (Bory de Saint-Vincent) Kützing (Gigartinales, Rhodophyta)}

C. variegata is a red alga exported as raw material for direct consumption in salads for its bright colors and high content of minerals and vitamins. In Chile, it is known by the common name of "carola". It is distributed in New Zealand, Australia, South Africa, South America, Antarctica and subantarctic regions (Guiry \& Guiry, 2012; Arakaki et al., 2011). In Chile, this species has been collected at numerous locations between Antofagasta $\left(23^{\circ} 38^{\prime} \mathrm{S}\right)$ and Cape Horn $\left(55^{\circ} 43^{\prime} \mathrm{S}\right)$. They form subtidal populations, where the fronds grow attached to rocks in semi-exposed or protected habitats, between $0-15 \mathrm{~m}$ in depth.

Experimental cultivation of this species has been attempted from carpospores (Hernandez et al., 2010). Phenological studies show that natural populations of Callophyllis in Chiloe have a marked seasonal cycle of abundance, with a maximum of $50 \mathrm{~g} / \mathrm{m}^{2}$ (dry weight) between January and March. (Escalona et al., 1998; Filun et al., 1999; Hernandez et al., 2010) and non-reproductive fronds can be found throughout the year.

C. variegata has flattened fronds branched dichotomously, of intense red color with a small disc of attachment, highly variable in morphology with a smooth texture, up to $30 \mathrm{~cm}$ in length (Figure $3 \mathrm{~A}-\mathrm{D}$ ). The life cycle is isomorphic; carposporophytic fronds with many prominent cystocarps are located at the edges of the branches, with 1 to 3 ostioles (Figure 3 D). The tetrasporangia differ in the cortex and are cruciately divided, distributed over the surface of the frond and hardly distinguishable to the human eye (Hoffmann \& Santelices, 1997, Arakaki et al., 2011).

Important brown macroalgae in the Magellan Region and Chilean Antarctica

Among the brown algae, the most representative and the largest is Macrocystis pyrifera, known as "huiro". In the Strait of Magellan, some of them are almost $30 \mathrm{~m}$ or more in length and can weigh more than $100 \mathrm{~kg}$, with holdfasts more than $80 \mathrm{~cm}$ in diameter and $70 \mathrm{~cm}$ high (Mansilla \& Avila, 2011).

These algae, which grow abundantly and form large subtidal beds similar to "Submarine Forests", provide environments that shelter fish, crustaceans, and mollusks, besides providing food and areas of reproduction for vertebrates and invertebrates and a substratum for fixation of a varied community of marine benthic algae (Mansilla \& Avila, 2011).

The macroscopic species of "huiros" are harvested for the extraction of alginates, used widely not only in the food industry, but also in the pharmaceutical industry. It is also used as food for the mollusk abalone, introduced into Chile and developed for export as a marine cultivated product. In Chile, investigations have been made of the use of this species as a food supplement for salmon (Mansilla et al., 2005).

The largest brown algae in the group is Durvillaea antarctica, commonly known in Chile as "cochayuyo". In Chile, "cochayuyo" serves as human food and its commercialization in different riverside cities and its transport by mule to cities in the interior and to Andean settlements play an important social role. A significant quantity of this alga is sold to companies that produce
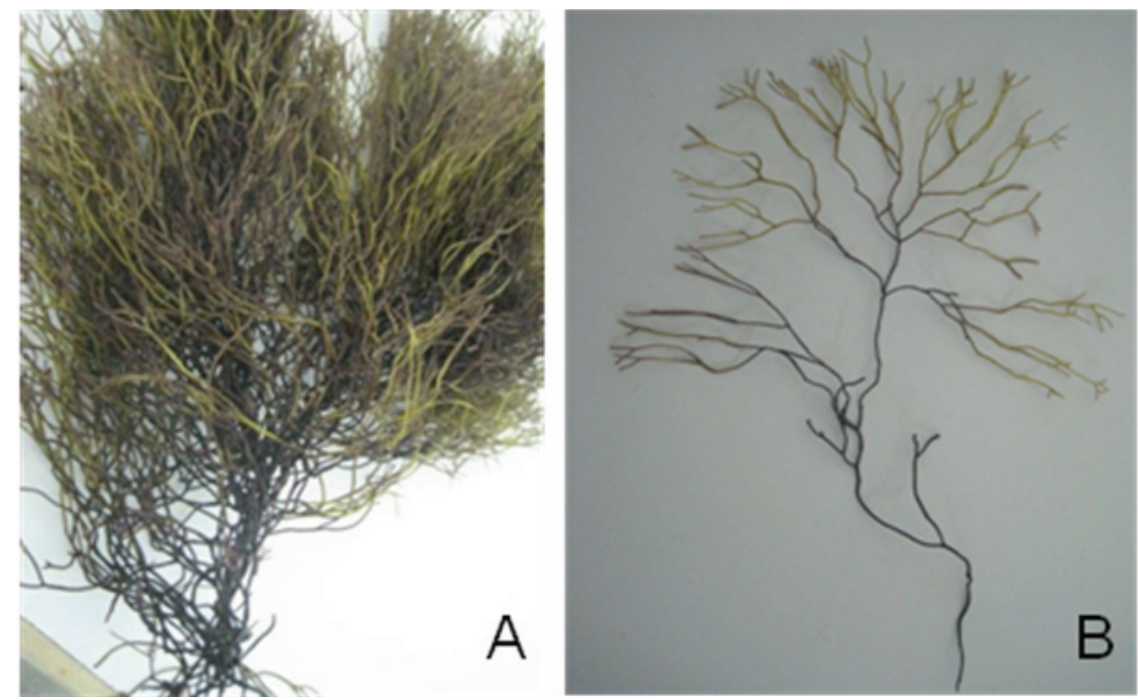

Figure 2. Ahnfeltia plicata (Ahnfeltiales, Rhodophyta): habitat (A) and detail of thallus (B) collected in Magellan Region, Chile. 

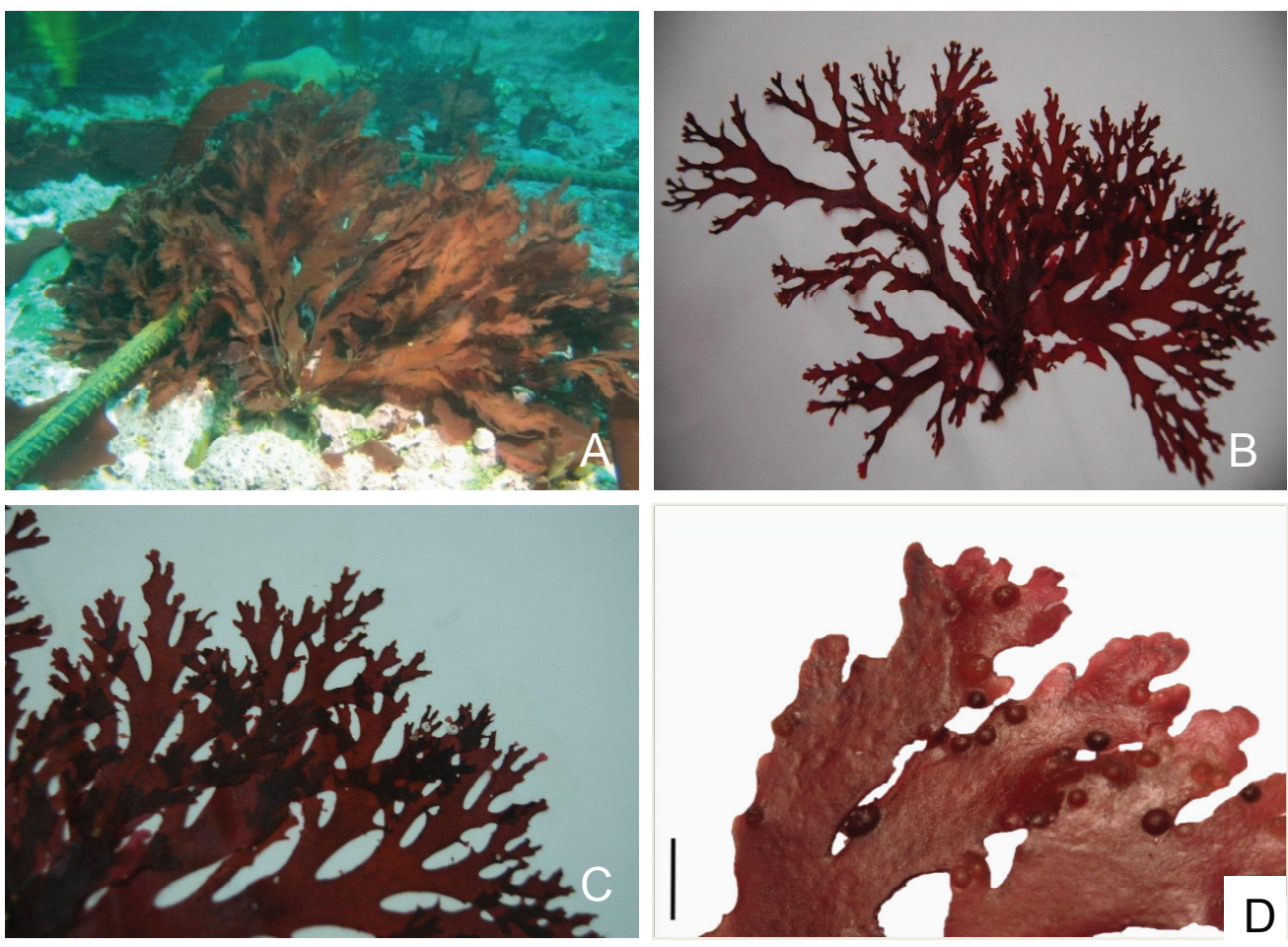

Figure 3. Callophyllis variegata (Gigartinales, Rhodophyta): habitat (A), general aspect of thallus (B), detail of thallus (C), and detail of cystocarps in female gametophyte (D) collected in Magellan Region, Chile. Scale $=3 \mathrm{~mm}$.

alginate for export, an industry that has suffered from the decrease in the quantities of existing natural beds.

During the last few years in Chile, important advances have been made in the biological knowledge of $M$. pyrifera and D. antarctica. These brown algae live in the intertidal and subtidal coastal zones, on hard substrata, normally in rocky zones, to which they stick and hold by means of a basal disc or holdfast. One of the most notable characteristics is their size (Santelices, 1989), especially the algae mentioned previously, whose fronds can reach several meters of length, and they form real submarine forests and belts that border along the coast. In clear waters, the species of this group can live at great depths.

\section{Durvillaea antarctica (Chamisso) Hariot (Fucales, Heterokontophyta)}

This resource is harvested on the shore in the central zone of Chile by collectors. The activity is done during low tide periods, when the stipes are cut from the basal region, the holdfasts remaining on the substrate (Castilla \& Bustamante, 1989; Bustamante \& Castilla, 1990). Fronds and dry stipes are used for direct human consumption, being commercialized in the local markets as ingredients for salads under the name of "ulte" or "Huilte" and in packages of dry whole or chopped alga under the name of "cochayuyo". Annually, important amounts are harvested (2307 ton), a percentage of this being exported as dry algae cut into strips under the name of "seaweed noodles" or as raw material for the alginate industry. Nowadays, the most important regions where this resource is collected are, in order of importance, the VIII, VI and X regions of Chile, whereas in the IV and $\mathrm{V}$ regions only minor volumes are extracted. In the Magellan Region, fresh and/or dry algae is used for the preparation of domestic recipes.

This species has been widely used in New Zealand; since 1960, it has been collected and used as forage for cattle and as fertilizer. Since the 1970's, it has been harvested for the production of alginate. Recent studies indicate that fronds of $D$. antarctica contain over $50 \%$ of dry weight of alginate with a FM value of 0.7 (Kelly \& Brown, 2000).

$D$. antarctica is a species endemic to the Southern Hemisphere, with a subantarctic distribution. In Chile, it is distributed from Coquimbo down to Cape Horn (Ramirez \& Santelices, 1991; Santelices, 1989). It is also found in New Zealand, Argentina (Tierra del Fuego), the Falkland/Malvinas Islands, Heard Island and McDonald Islands (Hoffmann \& Santelices, 1997; Vasquez, 2008). It grows on rocky substrates in the low intertidal zone up to approximately 10 or $15 \mathrm{~m}$ in depth. It is typical of very exposed zones and shares the substratum with species like Lessonia.

The thallus of $D$. antarctica is dark greenishbrown in color and can measure up to $15 \mathrm{~m}$ in length (Figure 4 A-D). They are fixed to the substratum by means 

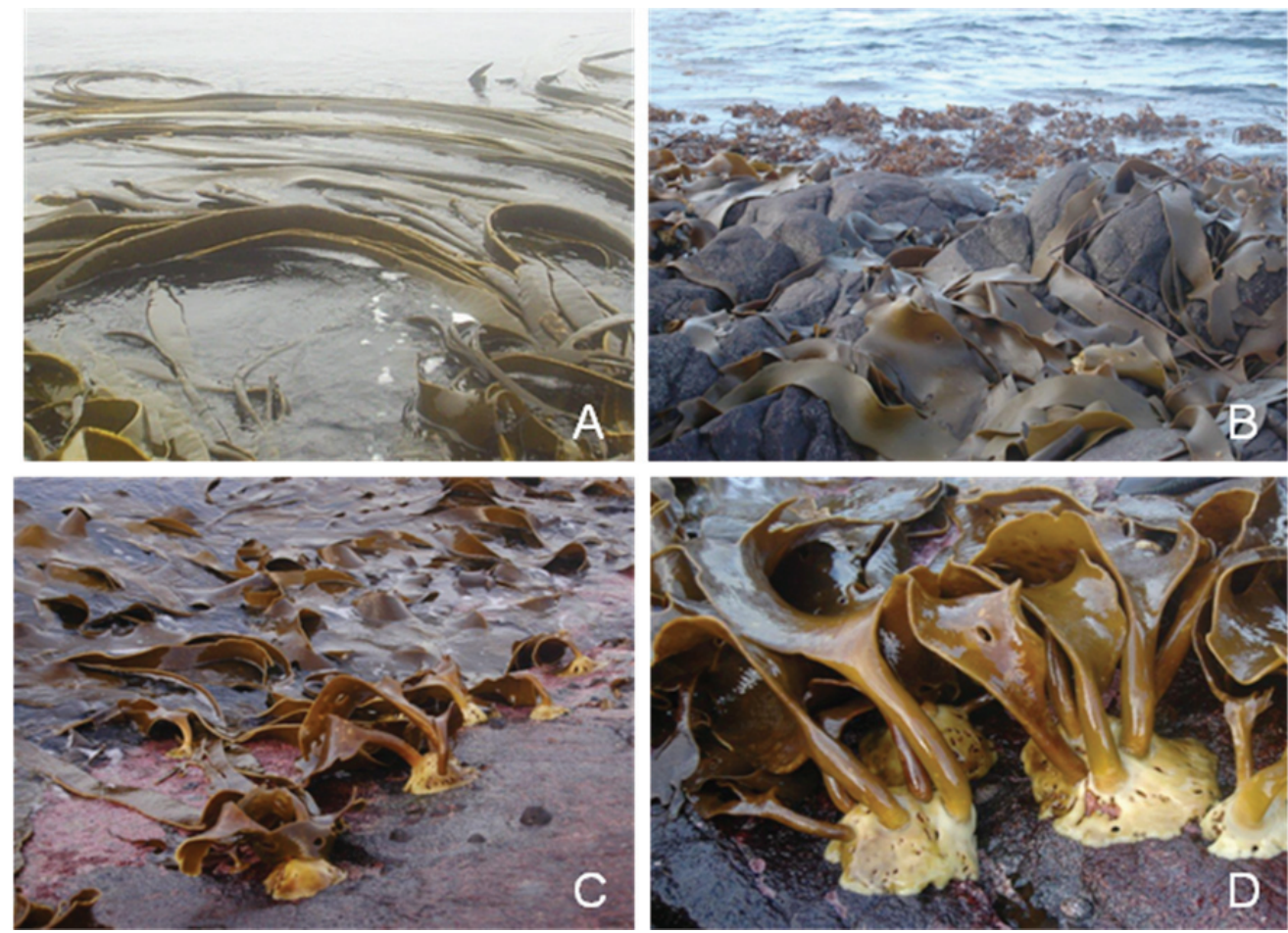

Figure 4. Durvillaea antarctica (Fucales, Heterokontophyta): habitat (A-B), general and detail aspects of holdfasts and stipes (C-D) of specimens from Magellan Region, Chile.
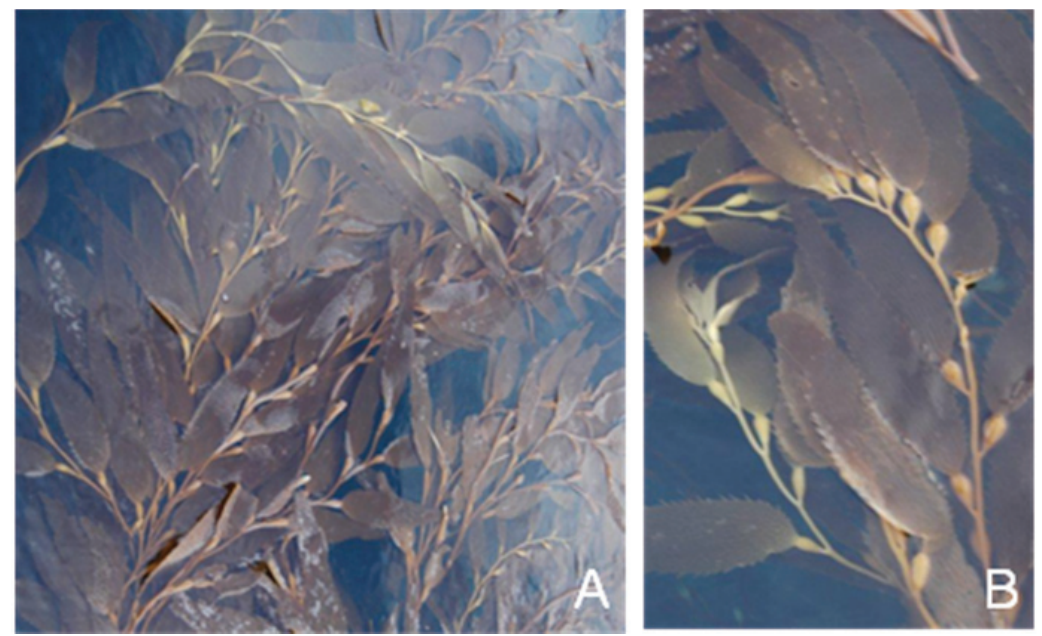

Figure 5. Macrocystis pyrifera (Laminariales, Heterokontophyta): habitat (A) and detail of thallus (B) of specimens from Magellan Region, Chile.

of a conical, compact disk of circular contour and smooth surface (Figure $4 \mathrm{C}-\mathrm{D}$ ). From the disc, a distally flattened thick cylindrical stipe is developed, forming thick fronds of coriacea consistency divided into many thin segments in the shape of thick tapes of different lengths that float on the surface of the sea. The life cycle is diplobiontic, with an independent diploid phase. The meiosis occurs in the gamotegenesis and corresponds to a dioecious species with small gametophytes of short duration (Buschmann et al., 1984).

\section{Macrocystis pyrifera (L.) C. Agardh (Laminariales, Heterokontophyta)}

This species is distributed from Tocopilla to Cape Horn and is used for the extraction of alginates and food. In the Magellan Region, the forests of M. pyrifera are distributed parallel to the coast, forming constant and irregular belts approximately 30 to $45 \mathrm{~m}$ in width.

M. pyrifera, commonly known like "huiro" or "Sargaso", corresponds to plants of large size that can 
measure up to $90 \mathrm{~m}$ of length (Figure $5 \mathrm{~A}-\mathrm{B}$ ). They stick fast to the substratum through a basal disc or holdfast formed by branched unfused haptera up to $1 \mathrm{~cm}$ in thickness (Hoffmann \& Santelices, 1997). Several cylindrical stipes arise from the disc, can be divided into two, and finish in elongated sheets provided with elongated basal air bladders. Between the terminal portion of the stipes and the base of the sheets, fissures are produced in the distal direction moving towards the edge of the sheet, producing the growth of stipes and sheets (Santelices, 1989; Hoffmann \& Santelices, 1997). The life cycle of Macrocystis pyrifera is heteromorphic and is characterized by the alternation of generations between an individual macroscopic diploid, corresponding to the sporophyte, and individual microscopic haploids, corresponding to female and male gametophytes.

Its utilization is mainly as a raw material for the production of alginates. Nevertheless, other important uses are: i) flour for supplementing the food of salmon, chickens, quails, sheep and bovines; ii) as a source of biofuels; iii) utilization of the carbohydrates to promote the growth of marine organisms of commercial interest; iv) as a biofertilizer for agricultural crops, and v) for human consumption through culinary recipes.

\section{Acknowledgements}

The authors thank support from PFB-23 (BasalCONICYT), P05-002 (ICM-MIDEPLAN), Project DO8I1163, and AQ08I1011 Fondef-Conicyt to AM and MA respectively. NSY thanks the CNPq for a research fellowship, and Conicyt for the Project MEC. E. Velasquez collaborated in the English translation and revision of the manuscript.

\section{References}

Arakaki N, Alveal K, Ramirez ME, Fredericq S 2011. The genus Callophyllis (Kallymeniaceae, Rhodophyta) from the Central-South Chilean coast $\left(33^{\circ}\right.$ to $\left.41^{\circ} \mathrm{S}\right)$, with the description of two new species. Rev Chil Hist Nat 84: 481-499.

Avila M, A Candia A, Nuñez M, Romo H 1999a. Reproductive biology of Gigartina skottsbergii (Gigartinaceae, Rhodophyta) from Chile. Hydrobiologia 398-399: 149157.

Avila M, Nuñez M, Candia A, Pavez H, Cortez H, Cornejo S 1999b. Informe final proyecto FIP N 99-22, 1999. Investigación y manejo de praderas de luga en la XII Región Ejecutor: Instituto de Fomento Pesquero. Fondo de Investigación Pesquera, p. 5-160.

Avila M, Cáceres J, Camus P, Candia A, Cortes H, Pavez H, Núñez M, González J 2003. Informe final proyecto FIP $\mathrm{N}^{\circ} 2001-28,2003$. Investigación y manejo de praderas de luga roja en la XI Región, Ejecutor: Instituto de Fomento Pesquero, Fondo Investigación Pesquera, p. 36-320.

Bischoff-Bäsmann B, Wiencke C 1996. Temperature requirements for growth and survival of Antarctic Rhodophyta. J Phycol 32: 525-535.

Buschmann A, Alveal K, Romo H 1984. Biologia de Durvillaea antarctica (Phaeophyta, Durvilleales) en Chile centroSur, morfologia y reproduccion. Memorias de la Asociacion Latinoamericana de Acuicultura 5: 399406.

Buschmann A, Varela D, Cifuentes M, HernándezGonzález M, Henríquez L, Westermeier R, Correa $\mathrm{J}$ 2004. Experimental indoor cultivation of the carrageenophytic red alga Gigartina skottsbergii. Aquaculture 241: 357-370.

Buschmann A, Hernández M, Aranda C, Chopin T, Neori A, Halling C, Troell M 2008. Mariculture waste management. In Jorgensen S, Fath B (eds) Ecological Engineering. vol. 3 of Encyclopedia of Ecology, Oxford: Elsevier, p. 2211-2217.

Buschmann A, Correa JA, Westermeier R, Paredes MA, Aedo D, Potin P, Aroca G, Hernández-González MC 2001. Cultivation of Gigartina skottsbergii (Gigartinales, Rhodophyta): recent advances and challenges for the future. J Appl Phycol 13: 253-265.

Bustamante RH, Castilla JC 1990. Impact of human exploitation on populations of the intertidal southern bull-kelp Durvillaea antarctica (Phaeophyta, Durvilleales) in central Chile. Biol Conserv 52: 205-220.

Castilla JC, Bustamante RH 1989. Human exclusion from rocky intertidal of Las Cruces, central Chile: Effects on Durvillaea antarctica (Phaeophyta, Durvilleales). Marine Ecol Progr Series 50: 203-214.

Correa J, Beltrán J, Buschmann A, Westermeier R 1999. Healing and regeneration responses in Gigartina skottsbergii (Rhodophyta, Gigartinales): optimization of vegetative propagation for cultivation. J Appl Phycol 11: 315-327.

Escalona M, Hernandez M, Gûttler P, Filun L, Aroca G, Vidal L, Cifuentes M, Westermeier R, Buschmann A 1998. Abundancia, fenologia y cultivo de Callophyllis variegata (Bory) Kützing (Rhodophyta): un alga comestible. Resumen XVIII Congreso Ciencias del Mar Sociedad Chilena de Ciencias del Mar, Iquique, Chile.

Filun L, Reyes B, Espinoza E, Buschmann A,Westermeier R 1999. Ecología de Callophyllis variegata (Gigartinales, Rhodophyta) en Punta Corona (Isla de Chiloé). Resumen XIX Congreso Ciencias del Mar sociedad Chilena de Ciencias del Mar, Antofagasta, Chile.

Comisión Nacional de Energía, 2007. Gobierno de Chile, CONICYT, Unión Europea 2007. "El sector de la energía en Chile, Capacidades de investigación y áreas de desarrollo científico-tecnológico". http://www.cne. gov.cl, accessed in Jun 2007.

Guiry MD, Guiry GM 2012. AlgaeBase. World-wide electronic 
publication, National University of Ireland, Galway. http://www.algaebase.org, accessed in Feb 2012.

Hernández-González M, Buschmann A, Cifuentes M, Correa J, Westermeier R 2007. Vegetative propagation of the carrageenophytic red alga Gigartina skottsbergii Setchell et Gardner: Indoor and field experiments. Aquaculture 262: 120-128.

Hernandez-Gonzalez MC, Aroca G, Furci G, Buschmann A, Filun L, Espinoza R 2010. Population dynamic and culture studies of the edible red alga Callophyllis variegata. Phycoll Res 58: 108-115.

Hoffmann AJ, Santelices B 1997. Flora marina de Chile central. Santiago: Ediciones Universidad Católica de Chile, $434 \mathrm{p}$.

Kelly BJ, Brown MT 2000.Variations in the alginate content and composition of Durvillaea antarctica and D. willana from southern New Zealand. J Appl Phycol 12: 317-324.

Kim DH 1976. A study of development of cystocarps and tetrasporangial sori in Gigartinaceae (Rhodophytta, Gigartinales). Nova Hedwigia 27: 1-146.

Maggs CA, Pueschel CM 1989. Morphology and development of Ahnfeltia plicata (Rhodophyta): proposal of Ahnfeltiales ord. nov. J Phycol 25: 333-351.

Mansilla A, Palacios M, Navarro N, Riquelme V 2005. Studies of the populations of Macrocystis pyrifera (L) C. Agardh in Tierra del Fuego, Chile. Rep Polar Mar Res 507: 160-162.

Mansilla A, Avila M 2011. Using Macrocystis pyrifera (L.) C. Agardh from southern Chile as a source of applied biological compounds. Rev Bras Farmacogn 21: 262 267.

Mansilla A, Navarro N 2003. Contribución al estudio de la flora ficológica de las Islas Diego Ramírez (Chile). Memorias de Curso Internacional de Postgrado y Especialización de macroalgas en ambientes subantárticos. Punta Arenas: Ediciones Universidad de Magallanes, p. 8590.

Mansilla A, Palacios M, Navarro NP, Avila M 2008. Utilization of agricultural fertilizers in the culture of Gigartina skottsbergii (Rhodophyta, Gigartinales) from the Strait of Magellan, Chile. J Appl Phycol 20: 889-896.

Ortiz JA, Barahona T, María Encinas V, Mansilla A, Matsuhiro B 2011. Caracterización estacional y determinación estructural del agarano neutro de Ahnfeltia plicata (Rhodophyta). XXIX Jornada de Quimica. VII Región, Chile.

Perez V 2000. Cronología de antecedentes para la Historia de las Ciencias Naturales de la Región de Magallanes: Siglo XVI al XIX. Ediciones de la Universidad de Magallanes, Punta Arenas, Chile.

Piriz ML 1996. Phenology of Gigartina skottsbergii Setchell et Gardner population in Chubut Province (Argentina).
Bot Mar 39: 311-316.

Ramírez ME 1995. Documentación y puesta en valor de la colección de algas marinas del Archipiélago de Juan Fernández, depositada en el Museo Nacional de Historia Natural. Informes Fondo de Apoyo a la Investigación, Centro de Investigación Barros Arana, DIBAM: p. 17-22.

Ramírez, M.E. y B. Santelices 1991. Catálogo de las algas marinas bentónicas de la Costa del Pacífico Temperado de Sudamérica. Monografías Biológicas 5. Pontificia Universidad Católica de Chile. Santiago, Chile. 433pp.

Romo H, Avila M, Nuñez M, Pérez R, Candia A, Aroca G 2006. Culture of Gigartina skottsbergii (Rhodophyta) in southern Chile. A pilot scale approach. J Appl Phycol 18: 307-314.

Rozzi R, Massardo F, Berghofer A, Anderson C, Mansilla A, Berghofer U, Jax K 2008. Changing lenses to assess biodiversity: patterns of species richness in sub-Antarctic plants and implications for global conservation. Front Ecol Environ 6: 131 -137.

Santelices B 1989. Algas marinas de Chile. Santiago: Ediciones Universidad Católica de Chile. 863 p.

Stanley NF 1987. Production, properties and use of carrageenans in productions and utilization of product from commercial seaweeds. Rome: Ed. DJ. McHugh, p. 97-147.

Vasquez J 2008. Production, use and fate of Chilean brown seaweeds: re-sources for a sustainable fishery. $\mathrm{J} \mathrm{Appl}$ Phycol 20: 457-467.

Westermeier R, Ramirez C 1978. Algas marinas de Niebla y Mehuín (Valdivia-Chile). Medio Ambiente 3: 44-49.

Westermeier R, Aguilar A, Sigel J, Quintanilla J, Morales J 1999. Biological basic for the management of Gigartina skottsbergii (Gigartinales, Rhodophyta) in southern Chile. Hydrobiologia 398/399: 137-147.

Westermeier R, Patiño DJ, Murúa P, Quintanilla JC, Correa J, Buschmann AH, Barros I 2012. A pilot-scale study of the vegetative propagation and suspended cultivation of the carrageenophyte alga Gigartina skottsbergii in southern Chile. J Appl Phycol 24: 11-20.

Wiencke C, Clayton MN 2002. Antarctic Seaweeds. vol. 9. Ruggell: Gantner Verlag KG.

Zamorano J, Westermeier R 1996. Phenology of Gigartina skottsbergii (Gigartinaceae, Rhodophyta) in Ancud Bay, southern Chile. Hydrobiology 326/327: 253-258.

\section{*Correspondence}

Andrés Mansilla

Laboratorio de Macroalgas Antárticas y Subantárticas, Universidad de Magallanes, Chile

Institute of Ecology and Biodiversity, Chile, andres.mansilla@umag.cl 